\title{
Denny Roy, Taiwan. A Political History
}

Ithaca and London, Cornell University Press, 2003, 256 p.

\section{Jean-Pierre Cabestan}

\section{OpenEdition}

\section{Journals}

Édition électronique

URL : http://journals.openedition.org/chinaperspectives/590

DOI : $10.4000 /$ chinaperspectives. 590

ISSN : 1996-4617

Éditeur

Centre d'étude français sur la Chine contemporaine

Édition imprimée

Date de publication : 1 février 2006

ISSN : 2070-3449

\section{Référence électronique}

Jean-Pierre Cabestan, « Denny Roy, Taiwan. A Political History », China Perspectives [En ligne], 63 |

january - february 2006, mis en ligne le 20 décembre 2006, consulté le 22 septembre 2020. URL

http://journals.openedition.org/chinaperspectives/590 ; DOI : https://doi.org/10.4000/

chinaperspectives.590

Ce document a été généré automatiquement le 22 septembre 2020

(c) All rights reserved 


\section{Denny Roy, Taiwan. A Political History}

Ithaca and London, Cornell University Press, 2003, 256 p.

Jean-Pierre Cabestan

\section{NOTE DE L'ÉDITEUR}

Translated from the French original by Philip Liddell

1 This book is a brilliant summary of Taiwanese political history: one could not recommend it more highly. Denny Roy, author of a book on Chinese foreign policy ${ }^{1}$ together with numerous articles on the politics of Taiwan and on relations between Taipei and Peking, has followed up here with a tour de force.

2 In eight densely written chapters, the author recounts the history of the island of Taiwan, this extraordinary human adventure, in all its twists and turns. The main benefit of this journey into the past is not merely the narration of this story. True, as others have done ${ }^{2}$, Roy skilfully takes us back to the early stages of the Formosa island story, to guide us through the various well-known periods of its development. The island is colonised a place of refuge for the Chinese general Koxinga, loyal to the Ming dynasty; it is annexed by the Manchu Empire, colonised by the Japanese, integrated into the Republic of China ; then it becomes the territorial base for that same Republic after the Communists' victory on the mainland. Finally we are plunged into that essential process of transition towards democracy, up to and beyond the victory in 2000 of the pro-independence candidate, Chen Shui-bian. But Roy's main contribution is to convey the complexity of this history and of its international ramifications, along with the uncertain future that the island faces in consequence.

3 This achievement is due to the author's mastery of his sources, both secondary and primary, but dominated above all by the latest historiographical work on Taiwan. Thus, he dismisses, again and again, the persistent untruths put about by various propaganda machines, communist, nationalist (in the Kuomintang sense) or pro-independence. We may cite just three examples. In 1895, the Taiwanese opponents of Japanese 
colonisation were not seeking independence but the return of Chinese "sovereignty" over the island; similarly, in 1945, the majority of the islanders welcomed with open arms the troops of Chiang Kai-shek閶only to see, as we know, their hopes drowned in blood two years afterwards; and the Japanese period is depicted in all its dimensions, bringing quite fairly to light, by means of numerous examples, the racism and cruelty of the Japanese colonisers who, while favouring the development of the island's economy (because it was in their interest), always treated the Taiwanese as inferior beings.

4 The complex nature of the relationship between Chiang and the United States is also given full weight. Relations were never good, and they might well have broken down completely had Kim Il-sung not conceived the dark design of invading South Korea in June 1950. Nevertheless, even after President Truman sent the American Seventh Fleet into the Taiwan Strait, contacts between Taipei and Washington were never easy, the Americans constantly trying not to upset Peking so as to defend their own strategic interests in the region (notably in Vietnam and in competition with the Soviet Union). In reading this book one can evaluate how the United States used Taiwan just as they wished, in their Cold War struggle against the Communist Bloc. Taiwan was a base for some CIA operations in China or in Indochina and thus had only a partial view of US concerns. Reading these pages (Chapter Five, p. 105 onwards) must inevitably encourage the reader to reflect on the present period and on the continuing limits imposed on the future of the island by its American protector...

5 The book's additional merit is to have studded the text with anecdotes, often little known but always eloquent : one such was how the Republic of China Navy "closed" the ports of the Chinese People's Republic (in reality, this was an armed blockade) between 1949 and 1953 (pp. 117-118) ; another recalls the impact on Taiwan of the Reynold affair in 1957, named after the American sergeant cleared by an American court martial after killing, apparently in self-defence, a Taiwanese man who had approached his private quarters in Taipei, an affair that also illustrates Chiang's duplicity towards the United States (pp. 135-136).

6 The account of the Lee Teng-hui years is forthright and balanced, placing in perspective events and decisions that many Taiwanese, especially those of the "blue" opposition, are today inclined to misrepresent. It is true that Lee did nothing殹or almost nothing茞to clean up the corruption in political circles. But in the former President's defence, his achievements easily outweigh his failures: against most expectations he marginalised the Kuomintang conservatives, promoted democracy by a series of constitutional reforms, drew the pro-independence opposition into political contention and even improved Taiwan's international standing, so much so that more people today can locate it on the map.

7 Of necessity, Roy has had to make choices, most of them welcome. Among those to be regretted, however, we should note that the chapter on Taiwan's first three hundred years of recorded history (from the seventeenth to the end of the nineteenth century)

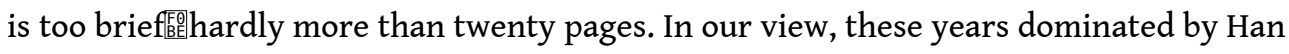
colonisation are important, for they help to explain the continuing prejudices among the mainland Chinese on the question of Taiwan.

We may also regret the failure to establish a strong connection between the democratisation process on the one hand and on the other the claim, if not to Taiwan's independence, then at least to "sovereignty": it was first put forward by Lee, is 
maintained today by Chen監and will be asserted tomorrow by any elected President of the Republic of China. Yet, accepting this dialectic is essential to understanding the constraints imposed on all those capitals involved, which includes Beijing and Washington.

9 A few errors and omissions should be pointed out. Hsieh Tung-min (incorrectly spelt on p. 92) was not Vice-President of the Republic in 1976 (p. 159). Similarly, Mao Zedong's acceptance in 1936 that Taiwan was not included among China's "lost territories" (and thus would not have to be regained) is attributed to an article in The Economist, when the known source for this comment is Edgar Snow's book Red Star Over China. But these are peccadillos. For all those who would wish, in 250 pages, to understand the political history of Taiwan, Denny Roy's is the book to read.

\section{NOTES}

1. China's Foreign Relations, London, Macmillan Press, 1998

2. For example, Murray Rubinstein, (ed.), Taiwan : a New History, Armonk, NY, M E Sharpe, 1999 